\title{
EFFECT OF ULTRASOUND PRETREATMENT ON WOOD PRIOR TO VACUUM DRYING*
}

\author{
Zhengbin He ${ }^{1}$, Zijian Zhao ${ }^{1}$, Fei Yang ${ }^{1}$, Songlin Yi $^{1,4}$
}

\begin{abstract}
The influence of ultrasonic pretreatment prior to vacuum drying of Chinese fir specimens was examined in this work. In the pretreatments, wood samples were immerged in a distilled water bath and were treated using two wave frequencies for four different elapsed times to investigate effects of ultrasonic frequency and treatment duration. Then the wood samples were vacuum-dried at $80^{\circ} \mathrm{C}$ and absolute pressure of $0,05 \mathrm{MPa}$. After the pretreatment, microscopic analysis was carried out on the wood samples to check micro-cracks, the loss of extractives from the cell walls and other micro-structural changes on the wood. Results show that the ultrasonic treatment prior to vacuum drying significantly shortened the wood drying time. The drying time decreased with increase in the wave frequency and the treatment time. Furthermore, ultrasound pretreatment tended to reduce the content of extractives in the wood cell walls and cause cell-wall micro-cracking.
\end{abstract}

Key words: Drying time, effective water diffusivity, ultrasound, wood vacuum drying.

\section{INTRODUCTION}

Wood drying is one of the most important steps in wood processing which consumes roughly 40 to $70 \%$ of the total energy in the entire wood processing and takes long time to complete (Zhang and Liu 2006). Wood vacuum drying offers the potential of fast drying and better drying quality in comparison to conventional drying operations (Ressel 1994). Some commercial vacuum drying operations can achieved drying rates which are 3-17 times faster than those of conventional drying (Harris and Taras 1984). However, vacuum drying methods are not suitable for timber with high initial moisture contents (Welling 1994), and surface checking and internal checking can be significant problems with wood vacuum drying when the drying temperature is high (Li et al. 2009); This is because of insufficient moisture movement from the center of the wood samples to the surface during the vacuum drying process which can cause steep moisture gradients from the core to wood surface layers; such gradients can lead to checking (Avramidis et al. 1994). In order to reduce the drying defects and to reduce the drying time, various methods of pretreatment of wood before drying have been reported to modify the material tissue structure (Madamba and Lopez 2002, Stojanovic and Silva 2006, Yong et al. 2006).

Ultrasound technology is based on mechanical waves at a frequency above the threshold of human hearing ( $>20 \mathrm{kHz})$ (Chandrapala et al. 2013). The ultrasonic pretreatment involves the immersion of the material in water or in a hypertonic aqueous solution or in other solutions to which ultrasound is applied (Fernandes et al. 2008). Ultrasonic waves can cause rapid series of alternative compressions and expansions, in a similar way to a sponge when it is squeezed and released repeatedly. In addition, ultrasound produces cavitation, a phenomenon produced by sonication, in the liquid which can explosively collapse and generate localized pressure (Wan 1992), and may be helpful to remove strongly attached moisture from solid material immerged in the liquid. The mechanical and physical effects of ultrasound

\footnotetext{
* This paper was originally presented at the 12th International IUFRO Wood Drying Conference July 30 to August 03, 2012, Belém, Para, Brazil.

${ }^{1}$ College of Material Science and Technology, Beijing Forestry University. Beijing, 100083, China.

•Corresponding author : ysonglin@126.com

Received: 02.08. 2013 Accepted: 14.11. 2013
} 
can be used to enhance many processes where diffusion takes place (Floros and Liang 1994). The sponge effect caused by ultrasound application may be responsible for the creation of microscopic channels in porous materials, such as fruits, that reduces the diffusion boundary layer and increases the convective mass transfer in the fruit (Tarleton 1992, Tarleton and Wakeman 1998, De La Fuente-Blanco et al. 2006).

In recent years, ultrasound has been implemented as an alternative pretreatment method for drying, and the results have shown that this pretreatment can greatly reduce the overall processing time (Duan et al. 2008, Aversa et al. 2011, Jangam 2011, Mothibe et al. 2011) which can attribute to the following factors: i). increase in the mass transfer rate (Garcia-Perez et al. 2009, Xu et al. 2009, Carcel et al. 2011, Garcia-Perez et al. 2011), ii). increase in the effective water diffusivity (Bantle and Eikevik 2011, He et al. 2012), iii). increase in wood specific permeability coefficient (Tanaka et al. 2010), iv). loss of cellular adhesion, v). formation of large cell interspaces, vi). rupture of the cell walls, and vii). formation of large channels (He et al. 2012).

In this work, ultrasound was used as a pretreatment method prior to vacuum drying. Pretreatment time and ultrasonic frequency levels were varied to determine their effects on vacuum drying time and the effective water diffusivity.

\section{MATERIALS AND METHODS}

\section{Material}

Chinese fir (Cunninghamia lanceolata (Lamb.) Hook) collected from Guangxi Province, China, was used as test specimens. The dimension of the test specimens was $100 \mathrm{~mm}$ long (Longitudinal) by 100 $\mathrm{mm}$ wide by $20 \mathrm{~mm}$ thick, with the initial moisture content of $70 \pm 2 \%$ (according to GB/T 1931-2009) (Zhao et al. 2009). To simulate the real production process, all the end cross-sections of specimens were blocked by covering them with wax.

\section{Ultrasound Pretreatment}

In each pretreatment experimental run, a set of six specimens was immersed in distilled water in an ultrasonic bath with internal dimensions: $300 \times 250 \times 200 \mathrm{~mm}$ (Cheng-Cheng Ultrasonics, Beijing, China, model VGT-2200A). After the distilled water was added into the ultrasound bath, the water bath with wood specimens in it was heated to and maintained at $40^{\circ} \mathrm{C}$ then ultrasound was applied to the bath. In the experiments, two ultrasound frequency of $28 \mathrm{kHz}$ and $40 \mathrm{kHz}$ were used with the same intensity of $300 \mathrm{~W}$ or equivalent to $4000 \mathrm{~W} / \mathrm{m}^{2}$. The ultrasound application timeshare were $0,5 \mathrm{~h} ; 1 \mathrm{~h} ; 1,5 \mathrm{~h}$ and $2 \mathrm{~h}$; respectively. The controlled temperature of $40^{\circ} \mathrm{C}$ was chosen because higher temperatures do not enhance the effects of ultrasound (Simal et al. 1998). Control specimens to be dried together with the ultrasound pretreated wood were not subjected to ultrasonic. For each condition, the experiments were carried out in triplicate.

\section{Vacuum Drying Procedure}

After pretreatment, the treated specimens and the control specimens were vacuum-dried (Yi et al. 2010 ) at $80^{\circ} \mathrm{C}$ and an absolute pressure of $0,05 \mathrm{MPa}$ (the saturated vapor pressure at the temperature of $80^{\circ} \mathrm{C}$ ). The mass of each specimen was recorded automatically by the weight scales (Hangzhou Bigle Tech., Hangzhou, China) at $2 \mathrm{~h}$ intervals. When the moisture contents reached $6 \%$, the specimens were oven-dried at $103 \pm 2{ }^{\circ} \mathrm{C}$ (Zhao et al. 2009), and drying rates for all the samples were obtained according to the weight during the drying procedure and the oven-dried. 


\section{Electron Microscope Scanning}

After drying, a section was selected randomly from each pretreatment condition and cut into 5 -mm cubes for image analysis using a scanning electron microscope (SEM, Hitachi S-3400N II, Tokyo, Japan).

\section{Effective Water Diffusivity}

The effective water diffusivity represents the ability of water to move within the wood during drying. The following equation was used to describe the falling-rate period of the drying process (Phoungchandang et al. 2008),

$$
M R=\left(M-M_{e}\right) /\left(M_{0}-M_{e}\right)=A \exp (-k t)
$$

Where $M R$ is non-dimensional moisture content (\%), $\mathrm{M}$ is moisture content at time t, $\mathrm{M}_{\mathrm{e}}$ is equilibrium moisture content, $M_{0}$ is initial moisture content at time $t=0, k$ is the drying rate constant $\left(\mathrm{s}^{-1}\right)$, and $t$ is the drying time (s).

Values of MR were plotted against time on semi-logarithmic graphpaper to obtain a $\ln M R$ - $t$ diagram. The slope of the line $k$ was a constant of the drying rate defined by equation (2)

$$
\mathrm{d} M R / \mathrm{d} t=-k\left(M-M_{e}\right)
$$

According to the linear relationship obtained from the $\ln M R$ - $t$ diagram, it was possible to apply Fick's second law of diffusion and obtain the effective diffusion of each specimen. The effective water diffusivity, $D_{e}\left(\mathrm{~m}^{2} \cdot \mathrm{s}^{-1}\right)$ could be calculated using $k$, the drying rate constant $\left(\mathrm{s}^{-1}\right), L$, the thickness $(\mathrm{m}), \pi$, constant with the value of 3,14 according to equation (3) (Marinos-Kouris and Maroulis 1995).

$$
\mathrm{D}_{\mathrm{e}}=k L^{2} / \pi^{2}
$$

\section{RESULTS AND DISCUSSION}

\section{Drying Time under Different Conditions}

In order to evaluate the effects of ultrasound pretreatment time and frequency levels on the vacuum drying time after pretreatment, the drying time at different conditions were presented in Figure 1.

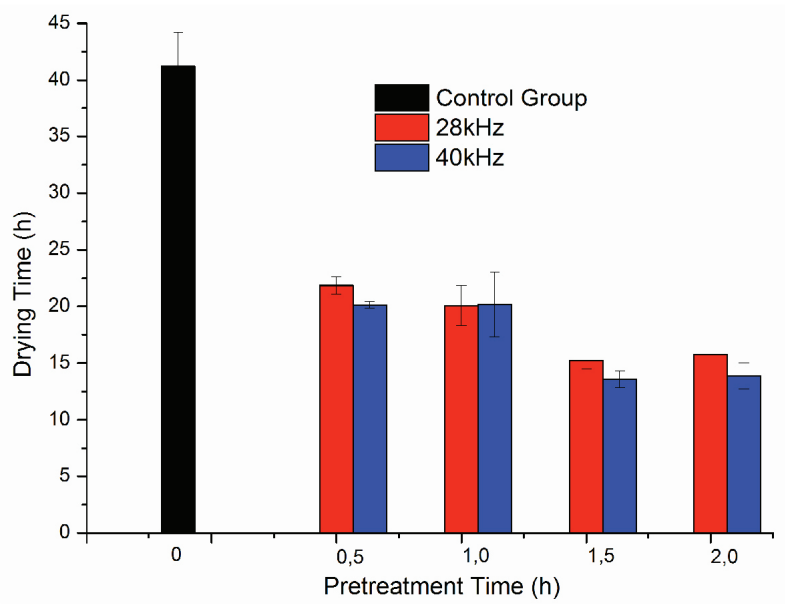

Figure1. Drying time of wood samples pretreated under different pretreatment conditions. 
Figure 1 shows that the drying time of the specimens pretreated by ultrasound was much shorter than that of the control specimens. It is also observed that the drying time was decreased with increase in the pretreatment time and in the ultrasound frequency. On average, the drying time for specimens pretreated with $28 \mathrm{kHz}$ ultrasound was 22;20;16 and $15 \mathrm{~h}$; respectively, for pretreatment time of 0,$5 ; 1 ; 1,5$ and $2 \mathrm{~h}$. With ultrasound frequency of $40 \mathrm{kHz}$, the corresponding drying time was 20,4;16,8;14,4 and 12,6 h. In contrast, the drying time for control specimens was $42,5 \mathrm{~h}$ for the specimens to reach the similar final moisture content. Therefore, differences in the drying time were significant between the ultrasound treated wood and the untreated samples $(\mathrm{p}<0.05)$ (Mathworks, matlab 7.0, America).

The decreased drying time, for specimens with ultrasound pretreatment, during the vacuum drying process could be due to the microscopic channels formed in the intercellular tissue and cell walls of the material, and the decrease of the extractives in porous wood with the ultrasound pretreatment. Similar phenomena have been observed in the previous publication (Duan et al. 2008, Fernandes et al. 2008a, Brncic et al. 2010, He et al. 2013).

\section{Effective Water Diffusivity}

Effective water diffusivities in wood samples were calculated using equation (3) based on the moisture content changes recorded during the drying period and the results are given in Table 1.

From Table 1, it can be seen that the effective water diffusivity increased with increasing pretreatment time. The effective water diffusivities of specimens pretreated at 0,$5 ; 1,0 ; 1,5$ and $2 \mathrm{~h}$; at the frequency of $28 \mathrm{kHz}$ were $2,17 \times 10^{-8} \mathrm{~m}^{2} \cdot \mathrm{s}^{-1} ; 2,41 \times 10^{-8} \mathrm{~m}^{2} \cdot \mathrm{s}^{-1} ; 3,03 \times 10^{-8} \mathrm{~m}^{2} \cdot \mathrm{s}^{-1}$ and $3,28 \times 10^{-8} \mathrm{~m}^{2} \cdot \mathrm{s}^{-1} ;$ respectively. At the frequency of $40 \mathrm{kHz}$, the corresponding effective water diffusivity values were $2,55 \times 10^{-8} \mathrm{~m}^{2} \cdot \mathrm{s}^{-1} ; 2,70 \times 10^{-8}$ $\mathrm{m}^{2} \cdot \mathrm{s}^{-1} ; 3,56 \times 10^{-8} \mathrm{~m}^{2} \cdot \mathrm{s}^{-1}$ and $3,83 \times 10^{-8} \mathrm{~m}^{2} \cdot \mathrm{s}^{-1}$ respectively. Therefore, the effective water diffusivity of the pretreated wood also increased with ultrasound frequency, to a less extent than the effect of pretreatment time. In comparison, the effective water diffusivity for the control specimens was $1,29 \times 10^{-8} \mathrm{~m}^{2} \cdot \mathrm{s}^{-1}$; which is 2 to 3 timeshare lower than those of pretreated specimens.

However, when the pretreatment time was longer than $1,5 \mathrm{~h}$; further increase in the effective water diffusivity was insignificant and the drying time was not expected to be decreased significantly. This is confirmed by the results presented in Figure 1. Therefore, there is no benefits to pretreat the wood for more than $1,5 \mathrm{~h}$.

Table 1. Effective Water Diffusivity of Wood $\left(D_{e}\right)$ at different pretreatment conditions.

\begin{tabular}{|c|c|c|c|}
\hline \multicolumn{5}{|c|}{ Effective water diffusivity $D_{\mathrm{e}} \times 10^{8} / \mathrm{m}^{2} \cdot \mathrm{s}^{-1}$} \\
\hline \multirow{2}{*}{ Pretreatment Time (h) } & \multicolumn{4}{|c|}{ Pretreatment } \\
\cline { 2 - 4 } & 28 & 40 & Control \\
\hline 0,5 & 2,17 & 2,55 & - \\
\hline 1,0 & 2,41 & 2,70 & - \\
\hline 1,5 & 3,03 & 3,56 & - \\
\hline 2,0 & 3,28 & 3,83 & - \\
\hline 0 & - & - & 1,29 \\
\hline
\end{tabular}


The increased effective water diffusivity during the wood vacuum drying process might be due to the phenomenon of cavitation during ultrasound pretreatment, the creation of microscopic channels in the intercellular tissue and the decreasing of the extracts content in porous wood. Our results were consistent with the previous reports by other researchers (Duan et al. 2008, Fernandes et al. 2008b, Brncic et al. 2010, He et al. 2012, He et al. 2013).

\section{Electron Microscopic Analysis}

The SEM micrographs of the samples before and after ultrasound pretreatment were presented in Figure 2 which shows that the ultrasound pretreatment had significant influence on the sample tissue structure and the content of extractives. It is well known that the extractives were formed by parenchyma cells at the heart $\neg$ wood-sapwood boundary and were then exuded through pits into adjacent cells (Hillis 1996). The extractives also make cells occluded and thus reduce wood permeability (Wiedenhoeft and Miller 2005). From Figure 2, it is observed that for the specimens without ultrasound pretreatment (Figure 2-a1 and Figure 2-a2), the pits aperture were occluded and lots of extractives were attached to wood tissue surfaces and in the parenchyma cells. However, for the wood samples pretreated with ultrasound for $1 \mathrm{~h}$, there were some collapses and microchannels on wood cells and the extractive content in parenchyma cells decreased (Figure 2-b1 and Figure 2-b2). The collapses might be caused by the cavitation of ultrasound during the pretreatment procedure. Furthermore, pits border were removed and most of the extractives on inner parenchyma cells disappeared and some cracks on cell wall appeared when the pretreatment time was $2 \mathrm{~h}$ (Figure 2-c1 and Figure 2-c2). This finding can be used to explain the reported observation that a longer ultrasound pretreatment time resulted in greater destruction of structure of material (Nowacka et al. 2012). Thus, the number of microchannels increased with the prolonged pretreatment time, and the longer the pretreatment time, the less content of extracts inner wood tissues.

Therefore, ultrasonic waves could promote cavitation and induce the formation of microchannels within the tissue of wood samples, and remove the extractives on the inner wood tissues, which could be found in many existing researches (Fernandes and Rodrigues 2007, Fernandes et al. 2008a, Fernandes et al. 2008c, Delgado et al. 2009, Fernandes et al. 2009, Cruz et al. 2011, Fernandes et al. 2011, Uribe et al. 2011). These microchannels and the decreasing extract might be considered to be mainly responsible for the shortened and reduced drying time.
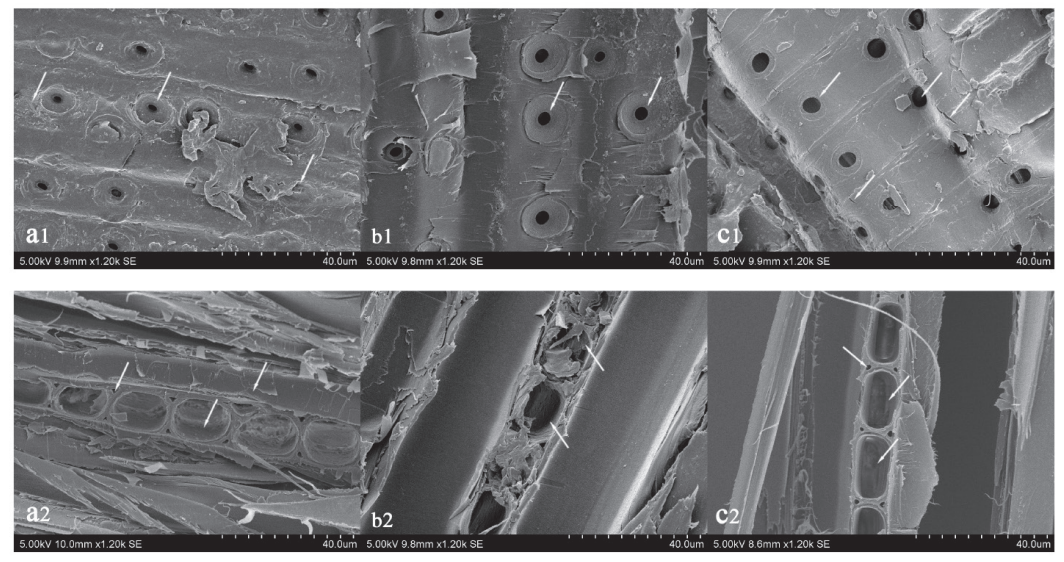

Figure 2. Photomicrograph of wood samples (1200×): (a1, a2) without pretreatment; (b1, b2) pretreatment carried out for $1 \mathrm{~h}$ at $28 \mathrm{kHz}$; (c1, c2) pretreatment carried out for $2 \mathrm{~h}$ at $28 \mathrm{kHz}$. 


\section{CONCLUSION}

The drying time of the specimens pretreated by ultrasound were much shorter than those of the specimens without ultrasound pretreatment during vacuum drying process. The drying time for the pretreated wood tends to decrease with the pretreatment time and the ultrasound frequency in the examined range.

The effective water diffusivity of pretreated wood is 2 to 3 times higher than the untreated wood and increases with increasing pretreatment time and, to a less extent, with ultrasonic frequency. However, the increase in the effective water diffusivity of pretreated wood is insignificant when the pretreatment time is longer than $1,5 \mathrm{~h}$.

The effect of ultrasound pretreatment can be explained by the changes in wood microstructure and removal of extractives. Ultrasound pretreatment could remove the pits border, reduce the amount of extractives on the inner wood pores and create some microcracks on wood cell wall.

\section{ACKNOWLEDGMENTS}

This paper was supported by the National Natural Science Foundation of China-Study on the moisture migration mechanism during ultrasonic-assisted wood vacuum superheated steam drying (31270604).

\section{REFERENCES}

Aversa, M.; Van Der Voort, A.J.; De Heij, W.; Tournois, B.; Curcio, S. 2011. An experimental analysis of acoustic drying of carrots: evaluation of heat transfer coefficients in different drying conditions. Drying Technology 29(2): 239-244.

Avramidis, S.; Liu, F.; Neilson, B.J. 1994 . Radiofrequency vacuum drying of softwoods - drying of thick western redcedar with constant electrode voltage. Forest Prod J 44(1): 41-47.

Bantle, M.; Eikevik, T.M. 2011. Parametric study of high-intensity ultrasound in the atmospheric freeze drying of peas. Drying Technology 29(10): 1230-1239.

Brncic, M.; Karlovic, S.; Rimac, B.S.; Penava, A.; Bosiljkov, T.; Jezek, D.; Tripalo, B. 2010. Textural properties of infra red dried apple slices as affected by high power ultrasound pre-treatment. Afr J Biotechnol 9(41): 6907-6915.

Carcel, J. A.; Garcia-Perez, J.V.; Riera, E.; Mulet, A. 2011. Improvement of convective drying of carrot by applying power ultrasoundinfluence of mass load density. Drying Technology 29(2): 174-182.

Chandrapala, J.; Oliver, C.M.; Kentish, S.; Ashokkumar, M. 2013. Use of power ultrasound to improve extraction and modify phase transitions in food processing. Food Rev Int 29(1): 67-91.

Cruz, R.M.S.; Vieira, M.C.; Fonseca, S.C.; Silva, C.L. M. 2011. Impact of thermal blanching and thermosonication treatments on watercress (nasturtium officinale) quality: thermosonication process optimisation and microstructure evaluation. Food Bioprocess Tech 4(7): 1197-1204.

De La Fuente-Blanco, S.; De Sarabia, E. R. F.; Acosta-Aparicio; V.M., Blanco-Blanco, A.; Gallego-Juarez, J.A. 2006. Food drying process by power ultrasound. Ultrasonics 44: 523-527. 
Delgado, A. E.; Zheng, L.; Sun, D.W. 2009. Influence of ultrasound on freezing rate of immersionfrozen apples. Food Bioprocess Tech 2(3): 263-270.

Duan, X.; Zhang, M.; Li, X.; Mujumdar, A.S. 2008. Ultrasonically enhanced osmotic pretreatment of sea cucumber prior to microwave freeze drying. Drying Technology 26(4): 420-426.

Fernandes, F.A.N.; Gallao, M.I.; Rodrigues, S. 2008a. Effect of osmotic dehydration and ultrasound pre-treatment on cell structure: Melon dehydration. Lwt-Food Sci Technol 41(4): 604-610.

Fernandes, F.A.N.; Gallao, M.I.; Rodrigues, S. 2009. Effect of osmosis and ultrasound on pineapple cell tissue structure during dehydration. J Food Eng 90(2): 186-190.

Fernandes, F.A.N.; Linhares, F.E.J.; Rodrigues, S. 2008b. Ultrasound as pre-treatment for drying of pineapple. Ultrason Sonochem 15(6): 1049-1054.

Fernandes, F.A.N.; Oliveira, F.I.P.; Rodrigues, S. 2008c. Use of Ultrasound for Dehydration of Papayas. Food Bioprocess Tech 1(4): 339-345.

Fernandes, F.A.N.; Rodrigues, S. 2007. Ultrasound as pre-treatment for drying of fruits: Dehydration of banana. J Food Eng 82(2): 261-267.

Fernandes, F.A.N.; Rodrigues, S.; Law, C.L.; Mujumdar, A.S. 2011. Drying of exotic tropical fruits: a comprehensive review. Food Bioprocess Tech 4(2): 163-185.

Floros, J. D.; Liang, H. H. 1994. Acoustically assisted diffusion through membranes and biomaterials. Food Technol-Chicago 48(12): 79-84.

Garcia-Perez, J.V.; Carcel, J.A.; Riera, E.; Mulet, A. 2009. Influence of the applied acoustic energy on the drying of carrots and lemon peel. Drying Technology 27(2):281-287.

Garcia-Perez, J.V.; Ozuna, C.; Ortuno, C.; Carcel, J.A.; Mulet, A. 2011. Modeling ultrasonically assisted convective drying of eggplant. Drying Technology 29(13): 1499-1509.

Harris, R.A.; Taras, M.A. 1984. Comparison of moisture-content distribution, stress-distribution, and shrinkage of red oak lumber dried by a radio-frequency vacuum drying process and a conventional kiln. Forest Prod J 34(1): 44-54.

He, Z.B.; Yang, F.; Peng, Y. Q.; Yi, S.L. 2013. Ultrasound-assisted vacuum drying of wood: effects on drying time and product quality. Bioresources 8(1): 855-863.

He, Z.B.; Yang, F.; Yi, S.L.; Gao, J.M. 2012. Effect of ultrasound pretreatment on vacuum drying of chinese catalpa wood. Drying Technology 30(15): 1750-1755.

Hillis, W. 1996. Formation of robinetin crystals in vessels of Intsia species. Iawa J 17: 405-420.

Jangam, S.V. 2011. An overview of recent developments and some R\&D challenges related to drying of foods. Drying Technology 29(12): 1343-1357.

Li, F.; Chen, L.Q.; He, Z.B.; Yi, S.L.; Zhang, B.G. 2009. Influence of vacuum medium condition on drying rate and drying defect. Drying Technology \& Equipment 7(6): 253-257.

Madamba, P.S.; Lopez, R.I. 2002. Optimization of the osmotic dehydration of mango (Mangifera indica L.) slices. Drying Technology 20(6): 1227-1242.

Marinos-Kouris, D.; Maroulis, Z. 1995. Transport properties in the drying of solids. Handbook of Industrial Drying 1: 113-159. 
Mothibe, K.J.; Zhang, M.; Nsor-atindana, J.; Wang, Y.C. 2011. Use of ultrasound pretreatment in drying of fruits: Drying rates, quality attributes, and shelf life extension. Drying Technology 29(14): 1611-1621.

Nowacka, M.; Wiktor, A.; Sledz, M.; Jurek, N.; Witrowa-Rajchert, D. 2012. Drying of ultrasound pretreated apple and its selected physical properties. J Food Eng 113(3): 427-433.

Phoungchandang, S.; Tochip, L.; Srijesdaruk, V. 2008. White mulberry leaf drying by tray and heat pump dehumidified dryers. World J Agric Sci 4(5): 844-851.

Ressel, B.J. 1994. State-of-the-art on vacuum drying of timber. Proceedings of the Fourth International IUFRO Wood Drying Conference, Rotorua, New Zealand: 255-262.

Simal Susana, J.B.; Sanchez, E.S.; Rossello, C. 1998. Use of ultrasound to increase mass transport rates during osmotic dehydration. J Food Eng 36(3): 323-336.

Stojanovic, J.; Silva, J. L. 2006. Influence of osmoconcentration, continuous high-frequency ultrasound and dehydration on properties and microstructure of rabbiteye blueberries. Drying Technology 24(2): 165-171.

Tanaka, T.; Avramidis, S.; Shida, S. 2010. A preliminary study on ultrasonic treatment effect on transverse wood permeability. Maderas. Ciencia y Tecnología 12(1): 3-9.

Tarleton, E. 1992. The role of field-assisted techniques in solid/liquid separation. Filtr Separat 29(3): 246-238.

Tarleton, E.; Wakeman, R. 1998. Ultrasound Food Process. Thomson Science, London, United Kingdom. 193-218.

Uribe, E.; Miranda, M.; Vega-Galvez, A.; Quispe, I.; Claveria, R.; Di Scala, K. 2011. Mass transfer modelling during osmotic dehydration of jumbo squid (dosidicus gigas): Influence of temperature on diffusion coefficients and kinetic parameters. Food Bioprocess Technology 4(2): 320-326.

Wan, P.J.; Muanda, M.W.; Covey, J.E. 1992. Ultrasonic vs nonultrasonic hydrogenation in a batch reactor. J Am Oil Chem Soc 69(9): 876-879.

Welling, J. 1994. Superheated steam vacuum drying of timber-range of application and advantages. $4^{\text {th }}$ IUFRO International Wood Drying Conference, Rotorua: 460-461.

Wiedenhoeft, A.C.; Miller, R.B. 2005. Handbook of wood chemistry and wood composites. CRC Press, Washington, D.C., United States of America . 12-13.

Xu, H.; Zhang, M.; Duan, X.; Mujumdar, A.S.; Sun, J. 2009. Effect of power ultrasound pretreatment on edamame prior to freeze drying. Drying Technology 27(2): 186-193.

Yi S.L.; Zhou Y.D.; He Z.B.; Feng X.J.; Zhang B.G. 2010. Equation of equilibrium moisture content of wood under vacuum by regression analysis. Adv Mater Res 139-141:645-648.

Yong, C.K.; Islam, M.R.; Mujumdar, A.S. 2006. Mechanical means of enhancing drying rates: Effect on drying kinetics and quality. Drying Technology 24(3): 397-404.

Zhang, B.; Liu, D. 2006. Exploring a new developing way of wood drying technology in China. China Forest Prod Ind 33(4): 3-6.

Zhao, R.J.; Fei, B.H.; Lv, J.X.; Yu, H.Q.; Huang, R.F.; Zhao, Y.Q.; Huang, A.M.; Cui, Y.Z. 2009. Wood moisture content measuring method. Wood-determination of moisture content for physical and mechanical test. MOD, CN-GB, GB/T 1931-2009. 